\title{
DESIGN AND DEVELOPMENT OF COCONUT PALM (Cocos nucifera L.) ROOF SHINGLES
}

\author{
by \\ A.R. Floresca, F.R. Siriban and A.P. Gesmundo ${ }^{1}$
}

\begin{abstract}
Tapered roof shingles from coconut wood were fabricated and treated separately with four preservatives, namely: copper-chromearsenate, pentachlorophenol, copper sulfate and copper sulfate + potassium dichromate. Untreated and treated shingles were installed side in roof framed structures and exposed outdoor in the FPRDI "graveyard" area for weather and durability tests.

Fabrication, treatment and installation costs of shingles were evaluated. Performance ratings on the different degradations such as splitting/checking and twisting of shingles, retention of original colour/appearance, and protection from weathering and fungal infection in relation to thickness, nailing patterns and treatments of coconut wood roof shingles after 11 months of weather exposure tests were evaluated and statistically analysed.
\end{abstract}

Cost comparison between coconut wood roof shingles and G.I. corrugated sheet gauge \#26 are also presented in this report.

\section{INTRODUCTION}

Shelter has always been a basic necessity of man. The most common housing materials are wood and wood products derived from premium and commercially known timber species. Due to the dwindling supply of traditionally-used timber for housing, the search for cheap and available substitute materials is imperative. The escalating cost of a housing unit is directly related to the increasing cost of labour and roofing materials such as G.I. sheets, ceramic shingles, asbestos and others.

The utilization of raw materials from coconut wood for roofing shingles will stimulate industrial interests and encourage a new business venture which can help solve the unemployment problem. Moreover, information gathered from this study will aid builders and the government in the smooth implementation of its human settlement programme because coconut wood would certainly augment needed materials for house construction and eventually bring its cost down.

Shingles are small, thin pieces of wood with parallel edges and tapering thickness in which one end is thicker than the other (Brown 1950; and Panshin et al 1962). Wood shingles are conventionally used as walling and roofing materials. The wood shingle industry has been established in the United States, Canada and some European countries. In the Philippines, Zamboanga Wood Products, Incorporated (Zambo Wood) in Zamboanga City started wood shingle manufacture in the latter part of 1960 . Until now, it is the only company known to produce wood singles from local timber species, namely: 1) tangile Shorea polysperma (Blanco) Merr./; 2) red lauan (shorea negrosensis Foxw.); 3) almon (Shorea almon Foxw.); 4) mayapis /Shorea palosapis z.) Dyer./;5) bagtikan /Parashorea malaanonan (Blanco) Merr./; and 6) tiaong (Shorea agsaboensis Stern) Eala et al 1979). It also manufactures wooden shingles for roofing from log ends generated from logpond trimmings.

\footnotetext{
${ }^{1}$ Researchers, Housing and Materials R\&D Division, Forest Products Research and Development Institute, Department of Science and Technology, College, Laguna 4031, Philippines.
} 
Wood for use in the manufacture of shingles should have the following properties: 1) durability; 2) free from splitting during nailing; 3) dimensional stability, i.e., low ratio of tangential to radial shrinkage and minimum shrinkage in all planes; 4) light weight; 5) good insulating properties; 6) adequate strength; 7) straight and even grain for ease of manufacture; 8) ability to take stain and paint; 9) ability to resist abrasion; and 10) pleasing appearance (Panshin et al 1962). Availability of sufficient supplies of raw materials at a reasonable cost is one important factor.

Under the ordinary method of using shingles in building construction, it was found (Browne 1947) that shingle materials from the heartwood of redwood and balcypress performed well without preservative treatment. It was also found that edge-grain shingles were much better than flat-grain shingles because they warped much less and withstood weathering better because shingles exposed to weather tend to curl. However, in commercial shingles from cedar, cypress and redwood the amount of curling is negligible. Superficial application of creosote, linseed oil or even used automobile crankcase oil will keep shingles from curling.

Eala et al (1979) reported that in 1978, the manufacturing cost of shingles at Zambo Wood was as follows: wood cost (at $31 \%$ recovery) $=12 \%$; labour cost $=33 \%$; supplies and operating cost $=32.9 \%$; and others $=22.1 \%$.

Shingles from coconut trunk had been fabricated at FPRDI but research on its utility and efficiency had not been extensively carried out. However, the Zamboanga Research Centre (ZRC) of the Philippine Coconut Authority (PCA) in San Ramon, Zamboanga City has successfully constructed model coconut wood houses roofed with coconut shingles (Escarillo Jr. 1984). The roof shingles were treated with copper-chromearsenate (CCA) and usually made of high density coconut wood. Each shingle was $102 \mathrm{~mm}$ wide, $406 \mathrm{~mm}$ long, and $4.8 \mathrm{~mm}$ thick at the thin end and $14.3 \mathrm{~mm}$ thick at the thicker end. Madrazo and Sulc (1983) cited the field exposure tests of treated coconut wood shingles for roofing materials by Palornar, R.N. and V.K. Sulc (1983). A study on the relative performance of three readily available inorganic chemicals containing either copper or chromium applied to sawn coconut timber had. also been conducted by Palomar and Sulc (1983).

In the survey conducted by Reyes (1976), roof materials used were found to be the least diversified and that the most commonly used of these materials was the G.I. sheet, in spite of the fact that it is expensive and gives the most heat discomfort. Probably the greatest drawbacks on the acceptance of nipa and cogon as roofing materials are their Short longevity or durability and inflarnmability. Reyes said nipa lasts 1-3 years. Cogon on the other hand, lasts only a year when installed at $13 \mathrm{~mm}$ thick and unbundled, but when bundled and with the proper slope of roof, cogon could last $10-15$ years.

A demonstration house roofed with treated cogon (Imperata cylindrica) was erected at the FPRDI towcost housing area in 1981 (Siopongco et al 1982). The efficiency of its parts has not yet been extensively studied.

The objectives of this study are to: 1) evaluate processing characteristics and properties and develop appropriate technology in the manufacture of roof shingles from coconut palm; 2) design and fabricate roof shingles from coconut palm; 3) develop construction techniques in terms of installation and weather protection; and 4) assess the actual cost and service ability of the roof materials installed.

\section{MATERIALS AND METHODS}

The wood materials used were obtained from coconut logs collected from Barangay Mainit, Bay, Laguna. 
The 3,000 mm long log samples (butt portion) of coconut were converted into 32 x $110 \mathrm{~mm}$ flitches, then air-dried for about 3 to 4 weeks. Coconut wood flitches with medium and high density were used for roof shingles. The flitches were planed to a uniform thickness of $25 / 27 \mathrm{~mm}$ and width of $102 \mathrm{~mm}$ prior to cutting into $406 \mathrm{~mm}$ long "blank" forms (Fig. 1). The blanks were sawn into tapered shingles using a simple wooden jig (Fig. 2) to hold the blank when fed manually to the table saw. The final product are two pieces of tapered shingles which were $102 \mathrm{~mm}$ wide, $406 \mathrm{~mm}$ long, and 4.8/6.4 $\mathrm{mm}$ thick at the thin end and 14.3/15.9 $\mathrm{mm}$ at the thicker end (Fig. 3).
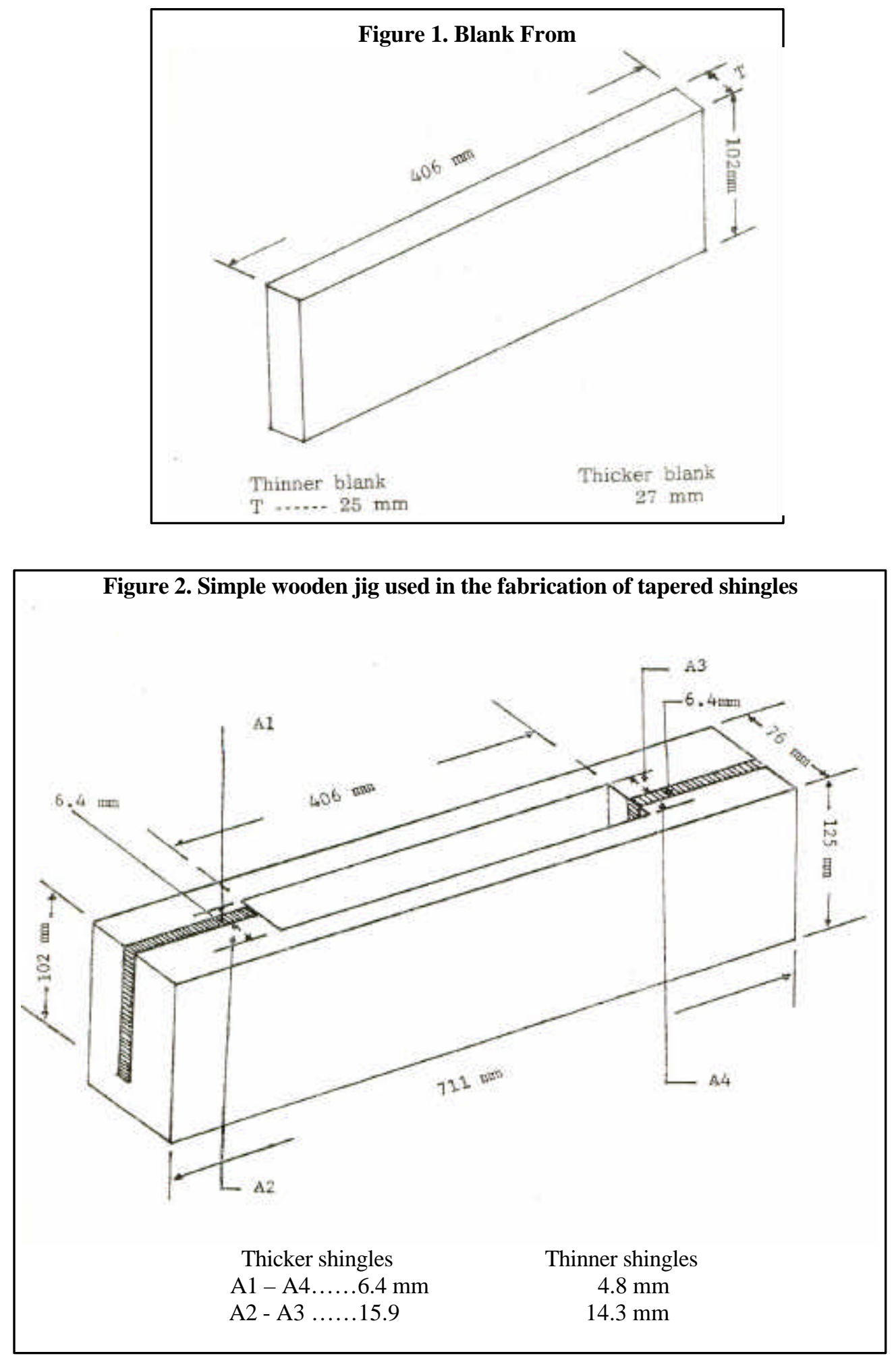
The shingles were treated separately by soaking in $8 \%$ solution of copper-chrome-arsenate (CCA), 5\% solution of copper sulfate (CS), and 5\% solution of copper sulfate + potassium dichromate (CS + PD) for three days and overnight in 5\% solution of pentachlorophenol (PCP) dissolved in diesel fuel. Eighteen shingles per treatment per thickness were used. Prior to treatment, the average moisture contents of medium and high density coconut shingles were about $17.0 \%$ and $17.8 \%$, respectively.

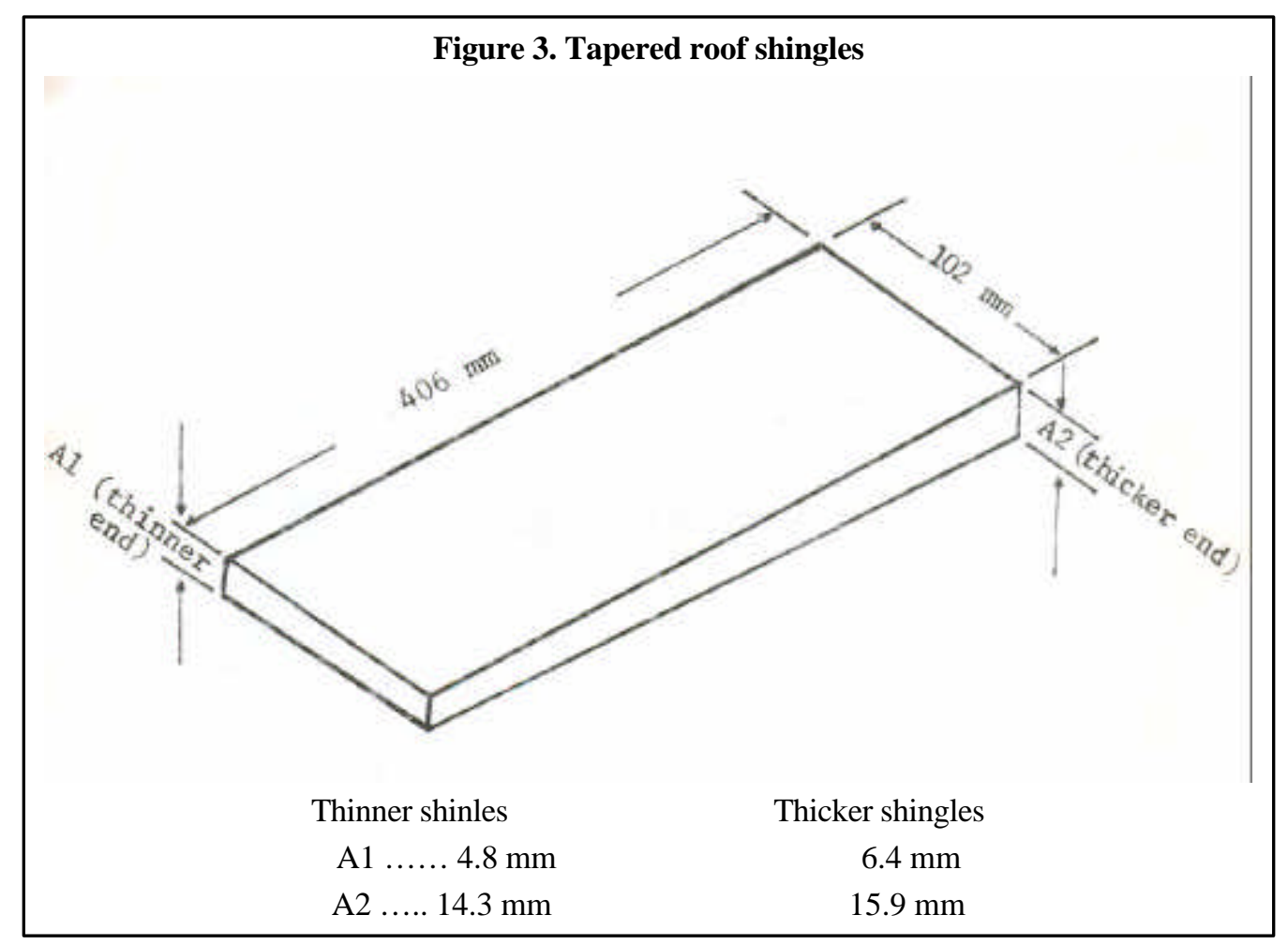

The treated and untreated roof shingles were histalled side by side in roof framed structures and exposed outdoof in the FPRDI "graveyard" area with 7/12 slope (Fig. 4). The shingles were exposed on January 6, 1986.

The shingles were installed by nailing them with a $38 \mathrm{~mm} \mathrm{CWN}$ to the $32 \mathrm{~mm}$ x $45 \mathrm{~mm}$ purlins spaced $165 \mathrm{~mm}$ o.c (Fig. 5). Installation of shingles began at the lowest portion of the roof framings. Shingles were installed by overlapping row by row from the caves to the ridge. A straight wooden board was used to guide rows of shingles during installation (Fig. 5). Two nailing patterns were applied, i.e., $50 \%$ of the shingles with 2 nails and the other $50 \%$ with only 1 nail.

The first row of shingles were installed so that the thicker ends were oriented at the caves and the thinner ends towards the ridge of the roof (Fig. 5). The thinner ends also coincided above the second purlin. Provision for swelling or expansion to prevent possible buckling or warping of shingles have been made by providing $3 \mathrm{~mm}$ spacing between the shingles when placed side by side. The shingles were nailed by driving 2 nails spaced $50 \mathrm{~mm}$ apart and edge distance of $25 \mathrm{~mm}$ thru the first purlin only. To prevent splitting, coconut shingles were prebored about $80 \%$ of the nail diameter prior to nailing. The protruding portion of shingles installed at the first row were trimmed at a distance of about $54 \mathrm{~mm}$ from the centre of the first purlin.

The second row of shingles was installed so that it covered the side joints of the first row of shingles (Fig. 5). The thicker ends were also oriented at the caves and the thinner ends exactly above the third purlin. Side spacing of shingles used was $3 \mathrm{~mm}$ apart. The shingles were nailed in the same manner as in the nails were driven through the second purlin. At this position, the thicker ends of the shingles were exactly $53.5 \mathrm{~mm}$ below the centre of the first purlin. 


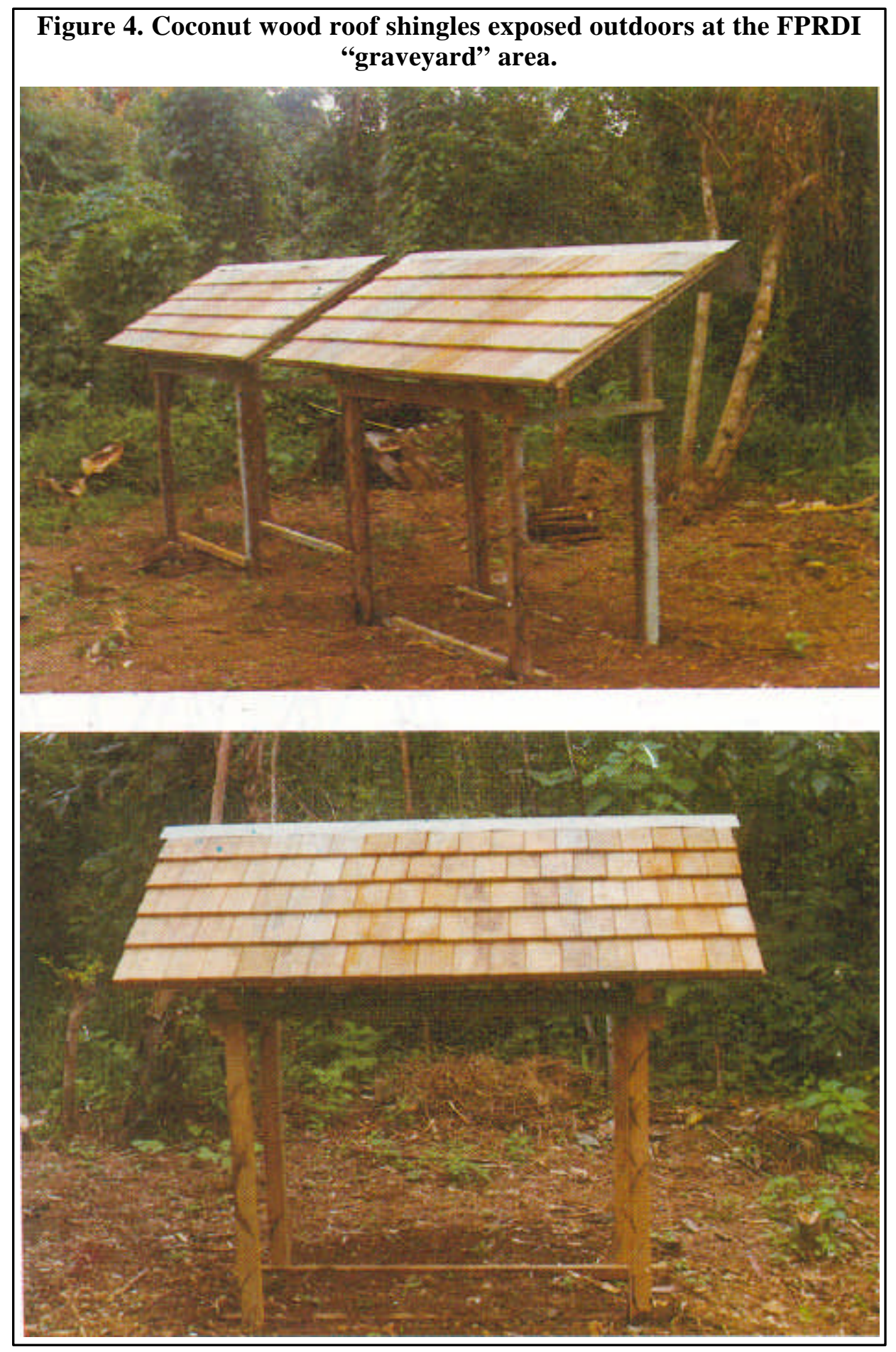

All succeeding, odd rows of shingles were installed in line and in the same manner as in the first row of shingles, except that only one nail per shingle was used. Singles in the even rows were also installed in line and in the same manner as in the second row of shingles. Only one nail per shingle was used in the $4^{\text {th }}$ row of shingle thru the purlins on which the thinner ends of proceeding row of shingles was resting.

The exposed shingles were periodically inspected to assess their performance with regards to splitting/checking on the nail portion, twisting of shingles., retention of original colour/appearance, weathering and fungal infection. The effect of nailing pattern was also 
investigated. The exposed shingles were evaluated after 11 months of outdoor exposure and the assessment was made based on the percentage ratings presented below:

Degree of splitting/checking $\quad \%$

1. No splitting/checking 100

2. Splits/checks, $102 \mathrm{~mm}$ long $\quad 75$

3. Splits/checks, $203 \mathrm{~mm}$ long 50

4. Splits/checks, $304 \mathrm{~mm}$ long 25

Degree of twisting

1. No twisting 100

2. Twist, $6.4 \mathrm{~mm}$ high $\quad 75$

3. Twist, $12.7 \mathrm{~mm}$ high $\quad 50$

4. Twist, $19.0 \mathrm{~mm}$ high 25

Retention of original colour/appearance

1. No significant change in colour/appearance $\quad 100$

2. Slight deviation from the original cleanliness andcolor but color remains uniform and pleasing $\quad 75$

3. Moderate change in appearance; needs refinishing $\quad 50$

4. Marked deviation from the original appearancewith displeasing colour $\quad 25$

Protection of wood surface from weathering/fungal infection

1. No significant weathering of surface

2. Slight softening of the surface fibersand brittle when proved resulting toa fiberless cork-like surface

3. Moderate softening of surface up toabout $4.5 \mathrm{~mm}$ deep

4. Deep softening with slight erosion ofthe the surface fibres

Analysis of variance on the performance ratings based on the different degradations of the coconut wood roof shingles was conducted using the Randomized Complete Block Design. Mean performance ratings were further compared using Duncan's Multiple Range Tests.

The cost of using coconut wood roof shingles was compared to G.I. corrugated 2 sheets using roof framing with an area of about $58 \mathrm{~m}^{2}$, using the exchange rate of US\$ $1=$ PHP20.00. 


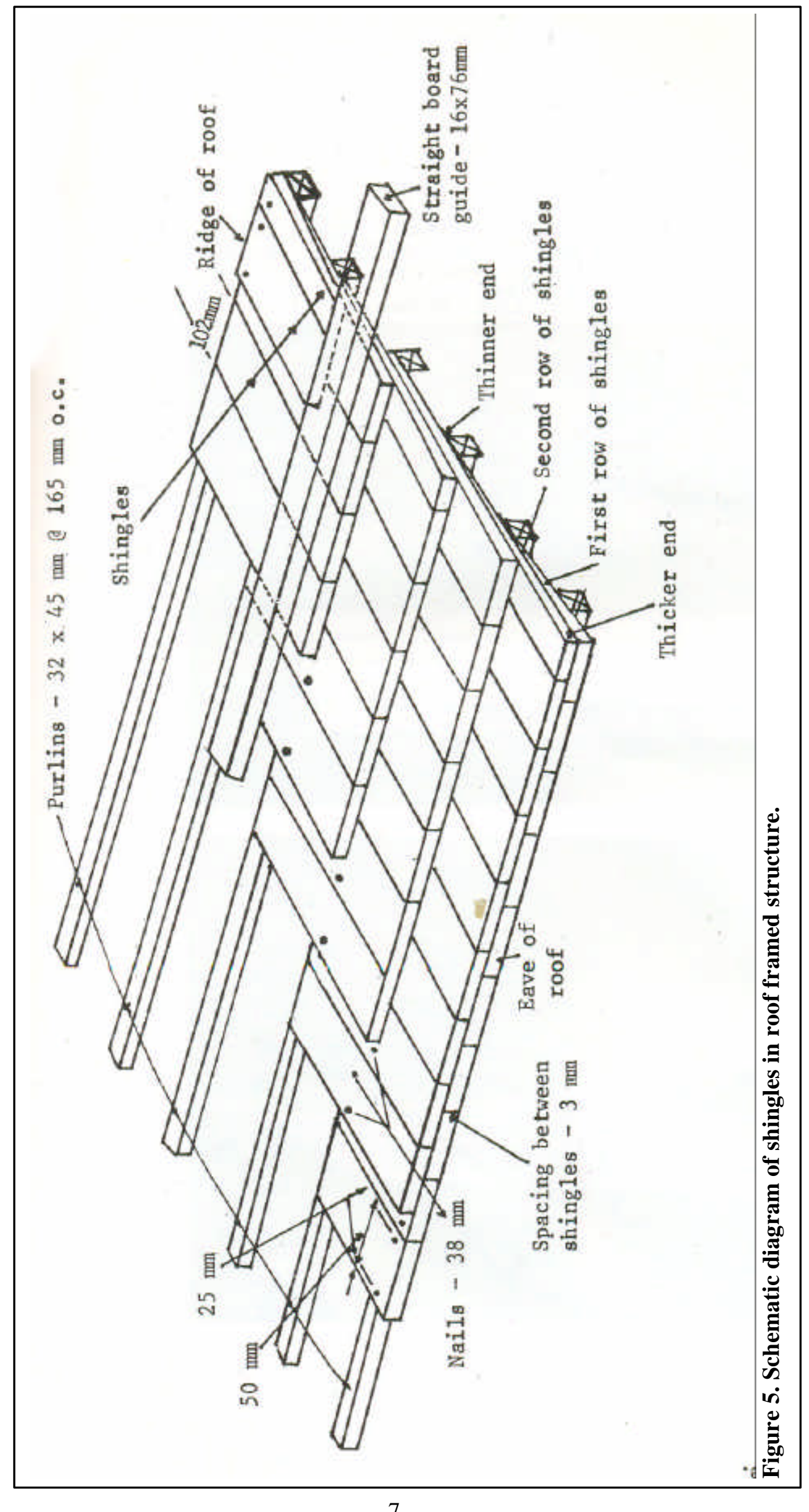




\section{RESULTS AND DISCUSSION}

The fabricated shingles from coconut wood had a width of $102 \mathrm{~mm}$ and length of $406 \mathrm{~mm}$ with thickness of 14.3/15.9 $\mathrm{mm}$ on one end and 4.8/6.4 mm on the other (Fig. 3). The estimated fabrication cost per shingle was about US $\$ 0.025$. The average time required for the fabrication of , a shingle was $3 \mathrm{~min}$. and $25 \mathrm{sec}$. The total number of coconut wood shingles that could be fabricated per hour from "blank" form to tapered shingles was 250 pieces. The average retention $\left(\mathrm{kg} / \mathrm{m}^{3}\right)$ and absorption $\left(\mathrm{g} / \mathrm{m}^{2}\right)$, and treatment cost per shingle for the different preservatives used are presented in Tables 1 and 2, respectively. Generally, thicker shingles and medium density coconut wood shingles had higher retention and absorption than thinner shingle and high density coconut wood shingles. This means that treatment cost per shingle was also higher in thicker and medium density coconut wood shingles than the thinner and high density coconut wood shingles. In the installation or laying of coconu wood shingles, it was estimated that the cost per m was US\$1.825 (Table 3).

The results of analysis of the variation in the performance ratings on the twisting and splitting of coconut wood roof shingles with respect to thicknesses, nailing patterns and treatments are presented in Table 4. The variation in performance ratings on the degree of twisting of both high and medium density shingles with respect to thicknesses, nailing patterns and treatments did not vary significantly. The degree of occurrence of the splitting of shingles with respect to thickness in both high and medium density wood, and nailing, patterns in medium density did not also vary significantly. Splitting of shingles with respect to the treatments in both high and medium density, and nailing patterns in high density, however, differed significantly as shown in Table 4. Results of further analysis of the extent of variation using Duncan's Multiple Range Tests are presented in Tables 5 and 6. The most suitable combinations of thickness, nailing pattern and treatment for high density coconut wood shingles will be any of the thicknesses with 2 nails and with treatment of either copper-chrome-arsenate or pentachlorophenol. In medium density coconut wood shingles, any of the thicknesses and nailing patterns and treatments of either pentachlorophenol or copperchrome-arsenate can also be used. In both the high and medium density coconut wood shingles, the thinner with 2 nails and treatment of copper-chrome-arsenate is preferred for economy and ease of installation.

The results of the analysis on the variation of performance ratings on the retention of original color/appearance and protection of surface from weathering of. coconut wood roof shingles with respect to thicknesses, treatments and densities after 11 months of exposure are presented in Table 7. The performance of the shingles with respect to thickness and densities did not vary significantly, but differed significantly with respect to treatments as shown in Table 7. The results of further analysis on the extent of variation using Duncan's Multiple Range Tests (Table 8) also showed that the three treatments were significantly different at $1 \%$ level of significance. There was no significant change in colour/appearance and weathering of surface observed in shingles treated with copper-chrome-arsenate, pentachlorophenol, and copper sulfate.

In the analysis of the variation of performance ratings on the protection of surface from fungal infection of both high and medium density coconut wood shingles after 11 months exposure, no significant effects were observed as shown by the " $F "$ ratios (Table 9). This may be due to the short period of exposure, i.e., 11 months in test only. 
Table 1: Average retention and absorption for the different treatments of Roof Shingles from coconut (Cocos nucifera $\mathbf{L}$.)

\begin{tabular}{|c|c|c|c|c|c|c|c|c|}
\hline \multirow[b]{2}{*}{$\begin{array}{l}\text { Density Thickness } \\
\text { Of shingles }\end{array}$} & \multicolumn{4}{|c|}{ Retention $\left(\mathrm{kg} / \mathrm{m}^{3}\right)$} & \multicolumn{4}{|c|}{ Absorption ( $\left.\mathrm{g} / \mathrm{m}^{2}\right)$} \\
\hline & $\begin{array}{l}\text { Copper- } \\
\text { Chrome } \\
\text { Arsenate }\end{array}$ & $\begin{array}{l}\text { Pontachlo- } \\
\text { Rophenol }\end{array}$ & $\begin{array}{l}\text { Coppper } \\
\text { Sulphate }\end{array}$ & $\begin{array}{c}\text { Copper } \\
\text { sulphate } \\
+ \text { pottasium } \\
\text { dichromate }\end{array}$ & $\begin{array}{l}\text { Copper- } \\
\text { Copper- } \\
\text { Arsenate }\end{array}$ & $\begin{array}{l}\text { Pontachlo- } \\
\text { Rophenol } \\
\text { Arsenate }\end{array}$ & $\begin{array}{l}\text { Coppper } \\
\text { Sulphate }\end{array}$ & $\begin{array}{c}\text { Copper } \\
\text { sulphate } \\
+ \text { pottasium } \\
\text { dichromate }\end{array}$ \\
\hline High Density & & & & & & & & \\
\hline $\begin{array}{l}\text { Thicker Shingles } \\
(6.4 \times 15.9 \times 102 \times 406 \text { mm })\end{array}$ & 7.852 & 4.804 & 5.357 & 5.051 & 82.556 & 50.509 & 56.325 & 53.108 \\
\hline $\begin{array}{l}\text { Thinner Shingles } \\
(4.8 \times 14.3 \times 102 \times 406 \mathrm{~mm})\end{array}$ & 6.982 & 4.853 & 4.900 & 4.604 & 64.662 & 44948 & 45.379 & 42.641 \\
\hline $\begin{array}{l}\text { AVERAGE } \\
\text { Medium density }\end{array}$ & 7.417 & 4.828 & 5.128 & 4.828 & 73.609 & 47728 & 50.852 & 47.874 \\
\hline Thicker shingles & 10.238 & 5.452 & 5.792 & 6.282 & 107.636 & 57.320 & 60.897 & 66.048 \\
\hline Thicker shingles & 9.907 & 6.164 & 5.780 & 7.081 & 91.754 & 57.087 & 53.533 & 65.582 \\
\hline AVERAGE & 10.072 & 5.808 & 5.786 & 6.682 & 99.695 & 57.204 & 57.275 & 65.815 \\
\hline
\end{tabular}


Table 2: Estimated average treatment cost per shingle of shingles from coconut (Cocos nucifera $L$ ) wood

\begin{tabular}{|l|r|r|r|r|}
\hline \multirow{2}{*}{\multicolumn{1}{|c|}{ Treatment }} & \multicolumn{4}{|c|}{ C o c o n u t } \\
\cline { 2 - 5 } & \multicolumn{2}{|c|}{ Highe density } & \multicolumn{2}{c|}{ Medium density } \\
\cline { 2 - 5 } & \multicolumn{1}{|c|}{ Thicker } & \multicolumn{1}{c|}{ Thinner } & \multicolumn{1}{c|}{ Thicker } & \multicolumn{1}{c|}{ Thinner } \\
\hline $\begin{array}{l}\text { Copper-chrome } \\
\text { Arsenate }\end{array}$ & US\$0.0085 & US\$0.0065 & US\$ 0.0110 & US\$0.0090 \\
Pentachlorophenol & 0.0014 & 0.0120 & 0.0160 & 0.0160 \\
Copper sulphate & 0.0025 & 0.0020 & 0.0030 & 0.0025 \\
$\begin{array}{l}\text { Copper sulphate + Potassium } \\
\text { dichromate }\end{array}$ & 0.0055 & 0.0040 & 0.0065 & 0.0065 \\
\hline
\end{tabular}

Table 3: Estimated average installation cost per Square Meter $\left(\mathrm{m}^{3}\right)$ of roof shingles from coconut (Cocos nucifera $L$.) wood

\begin{tabular}{|l|c|}
\hline \multicolumn{1}{|c|}{ Particular } & Coconut \\
\hline Installation of roof framed structure & US\$ 0.725 \\
Installation of shingles & US\$ 1.825 \\
\hline T O T A L & US\$2.55 \\
\hline
\end{tabular}


Table 4: Analysis of Variance of Performance Ratings on the twisting and splitting of Coconut (Cocos nucifera L.)

Wood Roof Shingles with Repeat to Thicknesses, Nailing Patterns and Treatments

\begin{tabular}{|c|c|c|c|c|c|c|c|c|}
\hline \multirow[b]{2}{*}{ Degradation } & \multirow[b]{2}{*}{ Sources of Variations } & \multirow[b]{2}{*}{$\begin{array}{l}\text { Degrees } \\
\text { Of Freedom }\end{array}$} & \multicolumn{3}{|c|}{ High Density } & \multicolumn{3}{|c|}{ Medium Density } \\
\hline & & & $\begin{array}{l}\text { Sum of } \\
\text { Square; }\end{array}$ & $\begin{array}{c}\text { Mean } \\
\text { Squares; }\end{array}$ & F-ratio ${ }^{1}$ & $\begin{array}{l}\text { Sum of } \\
\text { Squares }\end{array}$ & $\begin{array}{c}\text { Mean } \\
\text { Squares; }\end{array}$ & F-ratio ${ }^{1}$ \\
\hline \multirow{9}{*}{$\begin{array}{l}\text { Twisting of } \\
\text { Shingles }\end{array}$} & Between thickness & 1 & 162.25 & 162.25 & $.738276 \mathrm{NS}$ & 126.26 & 126.25 & .671749 NS \\
\hline & Between treatments & 4 & 845.5 & 211.625 & .962944 NS & 891.75 & 222.937 & $1.1862 \mathrm{NS}$ \\
\hline & Between nailing patterns & 1 & 168 & 168 & .76444 NS & 72.5 & 72.5 & $.385757 \mathrm{NS}$ \\
\hline & Interaction between Thickness and treatments & 4 & 373 & 93.25 & $.42431 \mathrm{NS}$ & 477 & 119.25 & $.63450 \mathrm{NS}$ \\
\hline & $\begin{array}{l}\text { Interaction between thicknesses and nailing } \\
\text { patterns }\end{array}$ & 1 & 944.75 & 944.75 & 4.29884 * & 80 & 80 & $.425663 \mathrm{NS}$ \\
\hline & Interaction between treatments and nailing patterns & 4 & 535.5 & 133.875 & $.609163 \mathrm{NS}$ & 750.5 & 187.625 & $.998312 \mathrm{NS}$ \\
\hline & $\begin{array}{l}\text { Interaction between thicknesses, treatments and } \\
\text { nailing patters }\end{array}$ & 4 & 764.5 & 191.125 & $.86966 \mathrm{NS}$ & 274.75 & 68.6875 & $.365471 \mathrm{NS}$ \\
\hline & Error & 160 & 35163 & 219.769 & & 219.769 & 30070.7 & 187.942 \\
\hline & Total & 179 & 38957.5 & & & 32743.5 & & \\
\hline \multirow[t]{9}{*}{$\begin{array}{l}\text { Splitting of } \\
\text { Shingles }\end{array}$} & Between thickness & 1 & 35.375 & 35.385 & .40726 NS & 80 & 80 & .899698 NS \\
\hline & Between treatments & 4 & 2757 & 689.25 & 7.9351 ** & 4478.12 & 1119.53 & $12.5905 * *$ \\
\hline & Between nailing patterns & 1 & 1421.87 & 1421.87 & 16.3696 ** & 18.625 & 18.625 & .20946 NS \\
\hline & Interaction between Thickness and treatments & 4 & 244.75 & 61.1875 & $.704431 \mathrm{NS}$ & 308.875 & 77.2187 & .868419 NS \\
\hline & $\begin{array}{l}\text { Interaction between thicknesses and nailing } \\
\text { patterns }\end{array}$ & 1 & 21 & 21 & $.241766 \mathrm{NS}$ & 5.5 & 5.5 & $.0618542 \mathrm{NS}$ \\
\hline & Interaction between treatments and nailing patterns & 4 & 144.875 & 36.2187 & .416974 NS & 112.5 & 28.125 & $.3163 \mathrm{NS}$ \\
\hline & $\begin{array}{l}\text { Interaction between thicknesses, treatments and } \\
\text { nailing patters }\end{array}$ & 4 & 905.5 & 226.375 & 2.60618 * & 386.75 & 96.6875 & $1.08737 \mathrm{NS}$ \\
\hline & Error & 160 & 13897.7 & 68.8609 & & 14227 & 88.9187 & \\
\hline & Total & 179 & 19428.1 & & & 19617.4 & & \\
\hline
\end{tabular}

${ }^{1}$ ns - Not significant

** - significant at the $1 \%$ level

* - significant at the $5 \%$ level 
Table 5: Variation of performance Ratings (\%) on the Splitting at the Nailed Portion of Medium Density Coconut (Cocos nucifera L.) Wood Roof Shingles with Respect to Treatments After 11 Months of Outdoor Exposure ${ }^{1 /}$

\begin{tabular}{|l|r|r|r|r|}
\hline \multirow{2}{*}{\multicolumn{1}{|c|}{ Treatment }} & \multicolumn{2}{c|}{ Thicker } & \multicolumn{2}{c|}{ Thinner } \\
\cline { 2 - 5 } & 1 nail & 2 nails & 1 nail & 2 nails \\
\hline Control (untreated) & $80.4(\mathrm{abc})$ & $89.2(\mathrm{a})$ & $83.7(\mathrm{abc})$ & $83.9(\mathrm{abc})$ \\
Copper-chrome-arsenate & $84.4(\mathrm{abc})$ & $91.9(\mathrm{a})$ & $86.4(\mathrm{abc})$ & $92.6(\mathrm{a})$ \\
Pentachlorophenol & $77.1(\mathrm{bcd})$ & $90.7(\mathrm{a})$ & $84.3(\mathrm{abc})$ & $91.4(\mathrm{a})$ \\
Copper Sulfate 75.9(cd), 74.8(cd), 83.9(abc) & $74.9(\mathrm{~cd})$ & & & \\
Copper Sulfate + Potassium dichromate & $83.8(\mathrm{abc})$ & $82.4(\mathrm{abc})$ & $67.9(\mathrm{~d})$ & $87.4(\mathrm{abc})$ \\
\hline
\end{tabular}

${ }^{1 /}$ Mean of 9 replicates. Means having the same letter are not significantly different at $5 \%$ level of significance (Duncan's Multiple Range Tests).

Table 6:- Variation of performance Ratings (\%) on the Splitting at the Nailed Portion of Medium Density Coconut (Cocos nucifera L.) Wood Roof Shingles with Respect to Treatments After 11 Months of Outdoor Exposure ${ }^{1}$

\begin{tabular}{|l|c|}
\hline \multicolumn{1}{|c|}{ Treatment } & Mean Value \\
\hline Control (untreated) & $94.1(\mathrm{~b})$ \\
Copper-chrome-arsenate & $93.5(\mathrm{a})$ \\
Pentachlorophenol & $95.6(\mathrm{a})$ \\
Copper sulfate & $87.8(\mathrm{~b})$ \\
Copper sulfate + Potassium dichromate & $89.4(\mathrm{~b})$ \\
\hline
\end{tabular}

${ }^{1 /}$ Mean of 36 replicates. Means having the same letter are not significantly different at 5\% level of significance (Duncan's Multiple Range Tests).

Table 7: Analysis of Variance of Performance Ratings on the Retention of Original Colour/ Appearance and Protection of Surface From Weathering of Coconut (Cocos nucifera L.) Wood Roof Shingles with Respect to Thicknesses, Treatments and Densities After 11 Months of Outdoor Exposure

\begin{tabular}{|l|r|r|r|r|}
\hline \multicolumn{1}{|c|}{ Source of Variations } & $\begin{array}{c}\text { Degrees } \\
\text { Of } \\
\text { Freedom }\end{array}$ & $\begin{array}{c}\text { Sum of } \\
\text { Squares }\end{array}$ & $\begin{array}{c}\text { Mean } \\
\text { Squares }\end{array}$ & F.-ratio ${ }^{1}$ \\
\hline Between thicknesses & 1 & 6.75 & 6.75 & $.277703 \mathrm{NS}$ \\
Between treatments2 & 2 & 14242.5 & 7121.25 & $292.977 * *$ \\
Between densities & 1 & 6.75 & 6.75 & $.277703 \mathrm{NS}$ \\
Interaction between thicknesses and treatments & 2 & -5 & -2.5 & $-.102853 \mathrm{NS}$ \\
Interaction between thicknesses and densities & 1 & -6 & -6 & $-.246847 \mathrm{NS}$ \\
Interaction between treatments and densities & 2 & -5.25 & 2.625 & $-.107996 \mathrm{NS}$ \\
Interaction between thicknesses, treatments and densities & 2 & 7 & 3.5 & $.143994 \mathrm{NS}$ \\
Error & 168 & 4083.5 & 24.3065 & \\
Total & 179 & 18330.2 & & \\
\hline
\end{tabular}

${ }^{1 /}$ NS - Not significant

** - Significant at the $1 \%$ level

${ }^{2 /}$ Control (untreated), Copper-chrome-arsenate/or Pentachlorophenol/or Copper sulphate, and Copper sulphate + Potassium dichromate. 
Table 8: Variation of Performance Ratings (\%) on the Retention of original Colour/ Appearance and Protection of Surface from Weathering of Coconut (Cocos nucifera L.) Wood Roof Shingles with Respect to Treatments After 11 Months of Outdoor Exposure

\begin{tabular}{|c|c|c|}
\hline Treatment & $\begin{array}{l}\text { Retention of Original } \\
\text { Color/Appearance }\end{array}$ & $\begin{array}{c}\text { Protection of Surface from } \\
\text { Weathering }\end{array}$ \\
\hline $\begin{array}{l}\text { Control (untreated) } \\
\text { Copper-chrome-arsenate/ } \\
\text { Or Pentachlorophenol } \\
\text { Or copper sulfate } \\
100 \text { (a) }\end{array}$ & $87.3(c)$ & $87.3(c)$ \\
\hline $\begin{array}{l}\text { Copper sulfate }+ \\
\text { Potassium dichromate }\end{array}$ & $97.5(b)$ & 97.5 (b) \\
\hline
\end{tabular}

Table 9: - Analysis of Variance of Performance Ratings on the Protection of Surface From Fungal Infection of High and Medium Density Coconut (Cocos nucifera L.) Wood Roof Shingles With Respect to atments After 11 Months of Outdoor Exposure

\begin{tabular}{|l|r|r|r|r|}
\hline \multicolumn{1}{|c|}{ Sources of Variation: } & $\begin{array}{c}\text { Degrees of } \\
\text { Freedom }\end{array}$ & Sum of Squares & Mean Squares & F-ratio ${ }^{1 /}$ \\
\hline Between treatments ${ }^{2}$ & 1 & 3126.72 & 3126.72 & $-560308 \mathrm{NS}$ \\
Error & 28 & -.15625 & -.00558036 & \\
Total & 29 & 3126.56 & & \\
\hline
\end{tabular}

${ }^{1 /}$ NS - Not significant

${ }^{2 /}$ Control (untreated), and Copper-chrome-arsenate/or Pentachlorophenol/or Copper sulfate/or Copper sulfate + Potassium dichrome

The estimated bill of materials for the cost study comparing coconut wood roof shingles and G.I. corrugated sheet \#26 roofing using roof framing with an area of about $58 \mathrm{~m}^{2}$ are presented in Table 10. To have a comprehensive comparison, all factors were taken into consideration, including not only the material costs but the differences in labour and framing costs inherent in the two types of roof construction (Figs. 6 and 7). The cost comparison between these two types of roof construction are presented in Table 11. Comparison shows that in coconut wood roof shingles (Fig 6), the labour cost was higher by about $16.43 \%$ but the materials were cheaper by about $5.93 \%$. On the total cost (Table 11), however, coconut wood roof shingles were still cheaper by about $1.23 \%$ than the G.I. corrugated sheet roofing (Fig. 7). In the comparison, the cost of coconut lumber for shingles was, the market sales price of US $\$ 74.20 / \mathrm{m}^{3}$. However, if the cost of coconut lumber is based on the production cost of US\$27.56 $\mathrm{m}^{3}$ Alcachupas et al 1984) coconut wood roof shingles was, $20.02 \%$ cheaper than the G.I. corrugated sheet roofing. An annual cost in place analysis would be appropriate but we don't know the service life of the shingles. 
Table 10: - Estimation and Bill of Materials for Cost Study of Coconut (Cocos nucifera L.) Wood Shingles Compared to Corrugated G.I. Sheets Roofing

\section{Description}

Cost

I. Gauge \#26 Corrugated G.I. Sheets

A. Roofing

1. Lumber (coconut wood). Rafters, ridge beam, fascia boards, purlins and cleats $1.014 \mathrm{~m}^{3}$ at US\$74.20/m

US\$ 75.239

2. G.I. Sheets:

a. Corr. G.I. shts. - 24 shts., Ga. \#26 x 3658mm(12') at US\$8.10/sht. (US\$2.21/linear m)

194.40

b. G.I. ridge roll - 4 pcs., Ga.\#26 x $460 \mathrm{~mm} \times 2440 \mathrm{~mm}$ at US\$2.90/pc.

11.60

c. G.I. flushing - 8 pcs., Ga.\#26 $\times 460 \mathrm{~mm} \times 2440 \mathrm{~mm}$ at US\$2.90/pc.

3. Nails:

a. Roof nails with lead washers - $10 \mathrm{~kg}, 51 \mathrm{~mm}(2 ")$ long at US\$1.25/kg

12.50

b. CWN (Assorted sizes, $25 \mathrm{~mm}$ to $102 \mathrm{~mm}$ (1" to 4"long) - $10 \mathrm{~kg}$ at US\$0.75/kg

Cost of Materials

4. Labour (2 men):

a. Installation of rafters, purlins and fascia boards - 6 days at US $\$ 3.50 / \mathrm{man} /$ day

42.00

b. Installation of corr. G.I. shts.flushing and ridge roll - 4 days at US\$3.50/man/day

28.000

Cost of Labour

* 1 US\$ = P 20.00 (1985)

B. Ceiling (Drop ceiling):

1. Lumber (coconut wood). Ceiling ig ists and hangers $-0.991 \mathrm{~m}$ at US $\$ 74.20 / \mathrm{m}^{3}$

US\$ 73.50

2. Ceiling board - 21 boards, $6 \mathrm{~mm} \times 1220 \mathrm{~mm} \times 2,440 \mathrm{~mm}$ std. lawanit at US $\$ 4.40 /$ board

3. Nails:

a. CWN (51 mm and $76 \mathrm{~mm}$ long)- $9 \mathrm{~kg}$ at US\$ 0.75/kg

6.75

b. Finishing nails (25 mm long) - $4 \mathrm{~kg}$ at US\$0.75/kg

3.00

Cost of Materials

4. Labour (2 men):

a. Installation of ceiling joists and hangers - 5 days at US\$3.50/man/day

35.00

b. Installation of ceiling boards - 4 days at US\$3.5/man/day

28.00

Cost of Labour

US\$ 63.00

II. Coconut Wood Shingles

A. Roofing

1. Lumber (coconut wood):

a. Rafters, ridge beam, facia boards and purlins - $1.230 \mathrm{~m}$ at US $\$ 74.20 \mathrm{~m}^{3}$

US\$ 91.266

b. Coconut wood shingles (Thinner - $102 \mathrm{~mm}$ wide, $406 \mathrm{~mm}$ long, and $4.8 \mathrm{~mm}$ thick at the thin end and $14.3 \mathrm{~mm}$ at the thicker end) $-3,886$ pcs:

1. Coconut wood for shingles $-2.924 \mathrm{~m}^{3}$ at US $\$ 74.2 / \mathrm{m} 3$

2. Fabrication cost at US\$0.25/shingle

3. Treatment (CCA) cost at US $\$ 0.008 /$ shingle 
2. G.I. ridge roll - 4 pcs., Ga. $\# 26 \times 460 \mathrm{~mm} \times 2,440 \mathrm{~mm}$ at US $\$ 2.9 / \mathrm{pc}$.

3. Nails:

a. CWN (Assorted sizes, $25 \mathrm{~mm}$ to $100 \mathrm{~mm}$ long) - $29 \mathrm{~kg}$ at US $\$ 0.75 / \mathrm{kg}$

b. Roof nails with lead washers (38 mm long) $-1 / 2 \mathrm{~kg}$ at US $\$ 1.25 / \mathrm{kg}$

Cost of Materials US\$ 470.44

4. Labour (2 men):

a. Installation of rafters, purlin, facia boards and ridge roll - 7 days at US $\$ 3.5 /$ man/day

US\$ 49.00

b. Installation I shingles (Area of roof $\left.=58 \mathrm{~m}^{2}\right)-U S \$ 1.825 / \mathrm{m}^{2}$

105.85

Cost of Labour US\$154.85

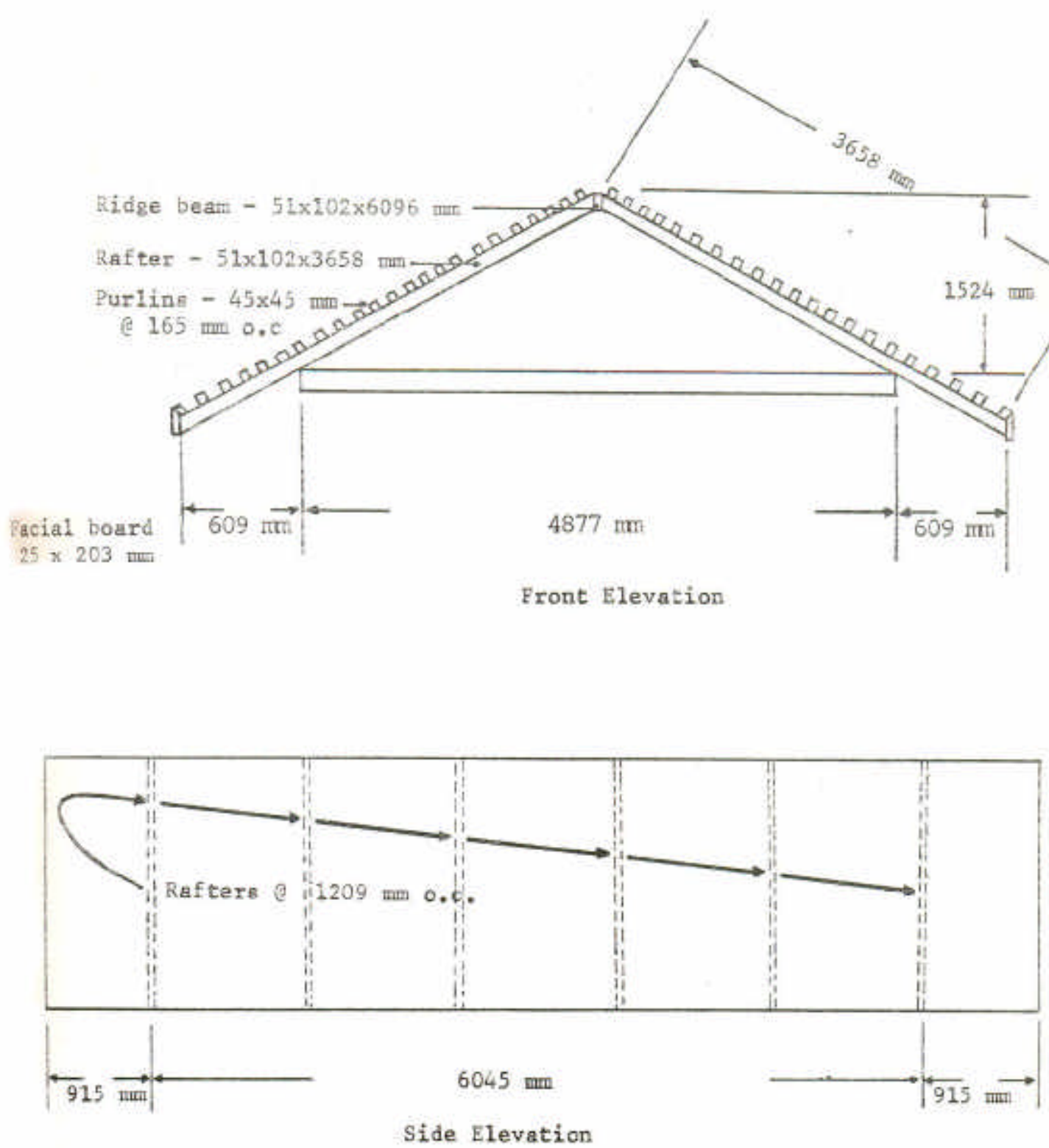

Figure 6. Typical Roof Framing for Coconut Wood Shingles. 

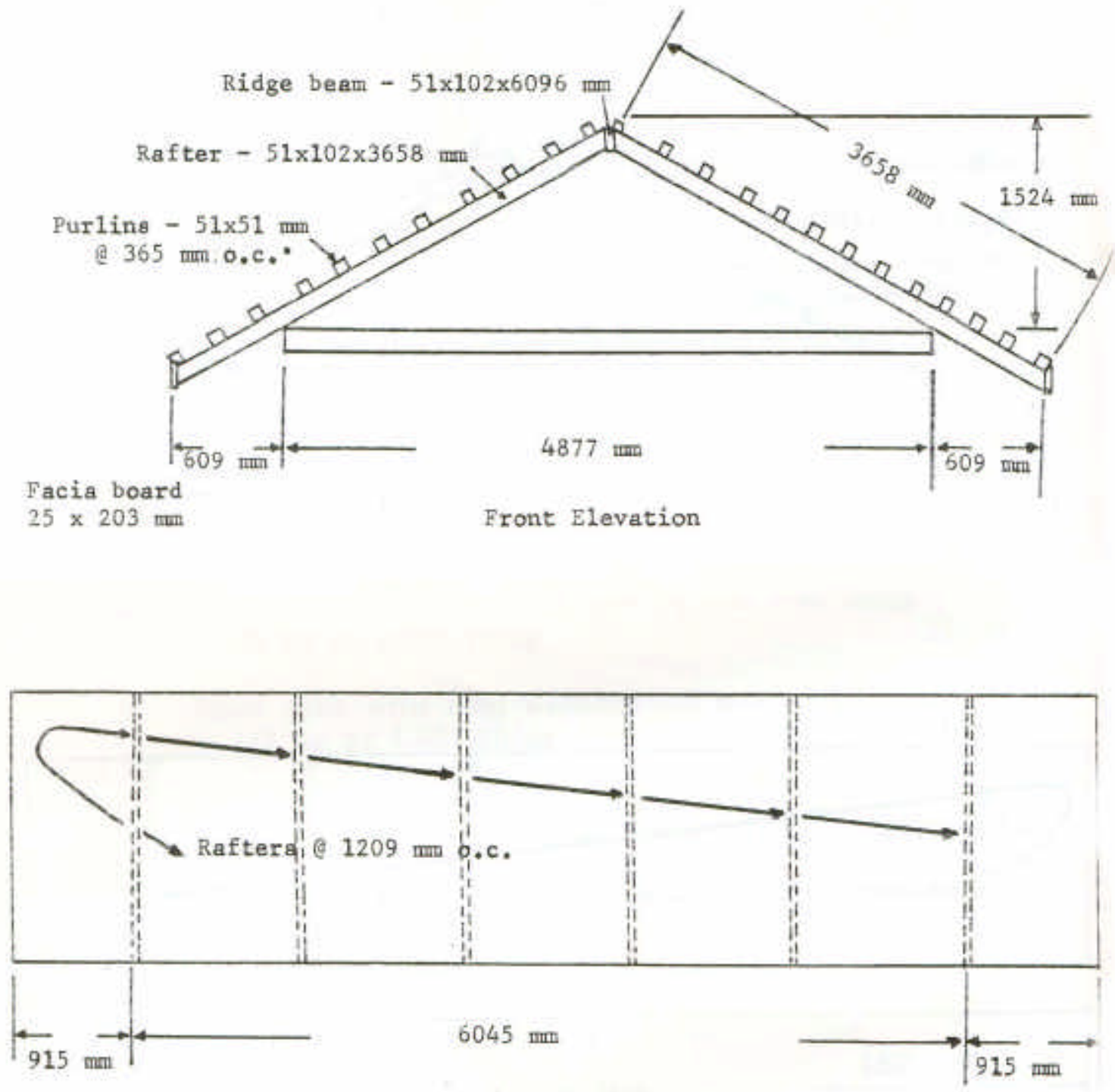

Side Elevation

Figure 7. Typical Roof Framing for G. I. Corrugated Sheets.

Comparing the cost of coconut wood shingles and G.I. corrugated sheet roofing, the following additional data were calculated:

\begin{tabular}{|l|l|l|}
\hline & G.I. Corrugated sheets & Coconut Wood Shingles \\
\hline No. of pieces $/ \mathrm{m}^{2}$ & $12 / 3$ & 67 \\
Costs $/ \mathrm{m}^{2}$ & US\$3.69 & US $\$ 5.963$ \\
Durability & 25 years & still undetermined \\
Purlins & Less purlins required & More purlins required \\
Ceiling & Needed & Not necessary \\
\hline
\end{tabular}


The data show that it is cheaper to, use G.I. corrugsted sheets than coconut wood shingles. The cost $/ \mathrm{m}$ for both roofings do not reflect the installation and hardware costs. The cost of G.I. corrugated sheets and coconut wood shingles are market sales price of US\$2.214/linear meter and fabrication and treatmpt, including cost of coconut lumber (US\$74.20/ $\mathrm{m}^{2}$ ) for shingles, respectively. In terms of production cost of coconut lumber (US $\$ 27.56 / \mathrm{m}^{3}$ ), cost $/ \mathrm{m}^{2}$ of coconut wood shingles was $2.40 \%$ cheaper than the G.I. corrugated sheets. The decision to use either coconut wood shingles or G.I. corrugated sheets should take into account not only the cost but also other factors like durability, aesthetic view/appearance, heat insulation and the need for additional structures like ceiling. G.I. corrugated sheet roofing makes a house very warm especially during summer. Hence, a ceiling becomes a necessary structure to absorb some of the heat from the G.I. sheets. Such ceiling is not necessary in a house roof with coconut shingles due to the heat insulating and sound proofing properties of wood shingles. The shingles will merely absorb the heat, thereby controlling the amount of heat inside the house.

\section{CONCLUSION AND RECOMIMENDATION}

In general, the service performance of the exposed treated coconut wood roof shingles can not yet be determined at this stage; the shingles are still in good condition after 11 months of outdoor exposure test. However, results showed that the most suitable combination of thickness, nailing pattern and treatment for high density coconut shingles is any of the thicknesses with two nails and with treatment of either copper-chrome-arsenate or pentachlorophenol. In medium density coconut shingles, any of the thicknesses ard railing patterns and with treatment of Either or copper-chrome-arsenate carl be used. In both high and medium density coconut wood shingles, the thinner shingle with two nails, and treated with copper-chrome-arsenate is preferred for economy and of installation.

In the cost comparison study, coconut wood roof shingles was $1.23 \%$ cheaper than the G.I.

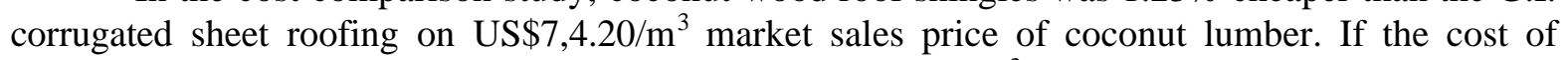
coconut lumber is based on the production cost of US $\$ 27.56 / \mathrm{m}^{3}$ coconut wood shingles is cheaper by $20.02 \%$ than the G.I. corrugated sheet roofing. Thus, the utilization of coconut wood shingles as roofing material seems encouraging for it will benefit the housing industry as well as coconut plantation owners. However, the durability of coconut wood shingles should be firmly established before its utilization as roofing materials is recommended. 


\section{REFERENCES}

Alcachupas, P. L., R. C. Eala an D. G. Quinones. 1984. Sawmilling and processing of coconut trunks into lumber and lumber products for flooring and sidings. Terminal Report. FPRDI Library. College, Laguna.

Brown, N. C. 1950. Forest Products. The harvesting, processing and marketing of materials other than lumber, including the principal derivatives, extractives and incidental products in the United States and Canada. $3^{\text {rd }}$ ed. John Willey and Sons, Inc. New York, Chapman and Hall Limited, London, pp. 117-126.

Browne, F. L. 1947. The preservative treatment and staining of shingles. USDA. FPL. No. R761.

Eala, R. C., D. G. Quinones and F.C. Ortiz. 1979. Wood shingle production. A special Report. FPRDI Library, College, Laguna.

Escarilia, J. A., Jr. 1984. Cocowood properties, grading and structural uses. Coconut Wood Utilization. Zamboanga Research Centre (ZRC), PCA, Zamboanga City.

Madrazo, R. M. and V. K. SuIc. 1983. Cocowood Utilization at ZRC. ZRC Report. ZRC, PCA, San Ramon, Zamboanga City.

Palomar, R. N. and V. K. Sulc. 1983.Exposure test of surface treated sawn coconut lumber. ZRC, PCA San Ramon, Zamboanga City.

Panshin, A. J., E. S. Harrar and F. S. Baker, 1962. Forest Products. Their sources, production and utilization. $2^{\text {nd }}$ ed. Mc-Graw Hill Book Company, London, pp.184-200

Reyes, V. D. 1976. A survey of bamboo joints and structures for domestic residential houses in Luzon. FPRDI Library, College, Laguna.

Siopongeo, J. O., F. M. Lauricio, F. R. Siriban and R. R. Valbuena. 1982. Development and service testing of non-traditional building materials of indigenous sources. NSTA Technology Journal. April-June, 1982.

\section{ACKNOWLEDGMENT}

Grateful acknowledgment are due to the Housing from Timber and Other Non-Timber Forest Products, and Utilities Construction personnel especially to the Research Assistants and Aides who fabricated, treated and installed the shingles and the wood collection teayn for the materials used in this study. Likewise, the authors extend their gratitude to those who conducted the statistical analysis and also to those who have reviewed and made corrections and suggestions in the preparations of this report. 